\title{
Pengaruh Pemberian Glukosa yang Berbeda terhadap Adaptasi Escherichia coli pada Cekaman Lingkungan Asam
}

\author{
The Effect of Different Glucose Administration on Escherichia coli Adaptation on \\ Acidic Environment Stress
}

\author{
R. R. S.Wihansah, M. Yusuf, M. Arifin, A. Y. Oktaviana, Rifkhan, \\ J. K. Negara, dan A. K. Sio
}

\author{
Ilmu Produksi dan Teknologi Peternakan Fakultas Peternakan \\ Sekolah Pascasarjana Institut Pertanian Bogor \\ Email : rafiatu225@gmail.com
}

\begin{abstract}
Every organism including bacteria have the ability to adapt to environmental conditions that do not conform to the comfort zone. This study aims to see the response of $E$. coli to acidic conditions as a form of adaptation. In this study there were five treatments, E. coli grown on Nutrient Broth media as controls (P0), E. coli grown on Nutrient Broth media with acidic conditions ( $\mathrm{pH} 4)(\mathrm{P} 1)$, E. coli grown on Nutrient media broth with acidic conditions ( $\mathrm{pH} 4)$ and glucose by $10 \%(\mathrm{P} 2)$, then given $30 \%$ glucose (P3) and $50 \%(\mathrm{P} 4)$. At each treatment was repeated 3 times. Total population was calculated by the method of turbidimetry using a spectrophotometer with turbidity value (OD). The results show that the media with a low $\mathrm{pH}(\mathrm{pH} 4)$ can inhibit the growth of E. coli, while the addition of glucose able to sustain the growth of E. coli bacteria. The addition of glucose to $50 \%$ proved to increase the population up to 29 hours, whereas the addition of glucose 10 and $30 \%$ had a decline in population of $E$. coli bacteria in 29 hours.
\end{abstract}

Key words : E.coli, adaptation, acid, bacteria population

\begin{abstract}
ABSTRAK
Setiap makhluk hidup termasuk bakteri memiliki kemampuan untuk beradaptasi pada kondisi lingkungan yang tidak sesuai dengan zona nyamannya. Penelitian ini bertujuan untuk melihat respon bakteri E.coli terhadap kondisi asam atau $\mathrm{pH}$ rendah sebagai bentuk adaptasinya. Pada penelitian ini terdapat 5 perlakuan yaitu E.coli yang ditumbuhkan pada media Nutrien Broth sebagai kontrol (P0), E.coli yang ditumbuhkan pada media Nutrien Broth dengan kondisi asam ( $\mathrm{pH}$ 4) (P1), E.coli yang ditumbuhkan pada media Nutrien Broth dengan kondisi asam ( $\mathrm{pH} 4$ ) dan diberi glukosa $10 \%(\mathrm{P} 2)$, selanjutnya diberi glukosa $30 \%$ (P3) dan $50 \%$ (P4). Pada setiap perlakuan diulang sebanyak 3 kali. Jumlah populasi dihitung dengan Metode Turbidimetri menggunakan spektrofotometer melalui nilai kekeruhan (OD). Hasil penelitian ini menunjukkan bahwa media dengan $\mathrm{pH}$ rendah ( $\mathrm{pH}$ 4) dapat menghambat pertumbuhan bakteri E.coli, sedangkan penambahan glukosa mampu mempertahankan pertumbuhan bakteri E.coli. Penambahan glukosa sampai $50 \%$ terbukti mampu meningkatkan populasi sampai jam ke 29, sedangkan pada pemberian glukosa 10 dan $30 \%$ sudah terjadi penurunan populasi bakteri E.coli pada jam ke 29.
\end{abstract}

Kata kunci: E.coli, adaptasi, asam, populasi bakteri

\section{PENDAHULUAN}

Setiap mahluk hidup membutuhkan makanan sebagai nutrisi untuk dapat bertahan hidup dan berkembang biak, tidak terkecuali mahluk hidup bersel satu yaitu bakteri. Selain nutrisi, faktor lain yang berpengaruh terhadap aktivitas perkembangbiakan bakteri adalah lingkungan yang optimal. Aktivitas bakteri secara signifikan dipengaruhi oleh faktor lingkungan yaitu $\mathrm{pH} . \mathrm{pH}$ adalah parameter untuk mengetahui intensitas tingkat kesamaan atau kebasaan dari suatu larutan yang dinyatakan dengan konsentrasi ion 
hidrogen terlarut. Bila $\mathrm{pH}$ lingkungan tidak sesuai untuk aktivitas bakteri secara optimal, maka bakteri tidak dapat melakukan metabolisme dengan baik.

\section{Bakteri sebagai mikroorganisme} uniseluler tidak dapat menguasai faktor faktor luar sepenuhnya, sehingga satu satunya cara untuk dapat hidup adalah dengan cara menyesuaikan diri atau beradaptasi dengan lingkungan sekitarnya. Dalam proses menyesuaikan diri dengan keadaan lingkungan sekitarnya ini, bakteri dapat beradaptasi dengan sangat cepat namun bersifat sementara waktu, atau bahkan terjadi perubahan secara permanen, sehingga dapat mempengaruhi bentuk morfologi serta sifat sifat fisiologi yang turun menurun.

Escherichia coli merupakan bakteri komensal yang dapat bersifat patogen, bertindak sebagai penyebab utama morbiditas dan mortalitas diseluruh dunia (Tenaillon et al., 2010). Keberadaan Escherichia coli dalam bahan pangan mengindikasikan bahwa telah terjadi kontaminasi dari feses/kotoran manusia atau hewan karena Escherichia coli secara normal ditemukan sebagai bagian dari flora usus manusia segera setelah manusia dilahirkan (Willshaw et al., 2000). Penelitian ini dilakukan untuk mengetahui daya adaptasi bakteri E.coli pada kondisi asam yang diberi perlakuan glukosa yang berbeda.

\section{MATERI DAN METODE}

Peralatan yang digunakan dalam praktikum ini antara lain sarung tangan, laminar, timbangan analitik, spatula, nampan, gelas ukur, batang pengaduk, $\mathrm{pH}$ meter, tabung reaksi, plastic wrap, autoclave, inkubator, refrigerator, pipet mohr, mikropipet, bunsen, spectrophotometer (Agilent Technologies), tisu. Adapun bahan-bahan yang digunakan pada praktikum ini antara lain nutrient broth, alcohol, glukosa, aquades, $\mathrm{CH}_{3} \mathrm{COOH}$ dan bakteri Escherichia coli.

\section{Persiapan Media Kultur NB (P0)}

Nutrien broth ditimbang sebanyak 0.65 gram lalu aquades dimasukkan ke dalam gelas ukur sebanyak $50 \mathrm{ml}$. Nutrient broth dimasukkan ke dalam gelas ukur yang berisi aquades tersebut kemudian diaduk sampai homogen. Larutan dibagi ke dalam 4 tabung reaksi masing-masing sebanyak 10 $\mathrm{ml}$ menggunakan pipet mohr. Larutan yang sudah siap kemudian disterilisasi menggunakan autoclave dengan suhu 121 ${ }^{0} \mathrm{C}$ selama 15 menit.

\section{Persiapan Media Kultur NB + pH 4 (P1)}

Nutrien broth ditimbang sebanyak 0,65 gram lalu Nutrient broth dimasukkan ke dalam gelas ukur yang berisi aquades sebanyak $50 \mathrm{ml}$. Ditambahkan larutan $\mathrm{CH}_{3} \mathrm{COOH}$ sampai mencapai $\mathrm{pH}$ 4. Untuk memastikan $\mathrm{pH}$ mencapai 4, digunakan pHmeter. Larutan dibagi ke dalam 4 tabung reaksi masing-masing sebanyak $10 \mathrm{ml}$ menggunakan pipet mohr. Larutan yang sudah siap kemudian disterilisasi menggunakan autoclave dengan suhu 121 ${ }^{0} \mathrm{C}$ selama 15 menit 
Persiapan Media Kultur NB + pH 4 + Glukosa 10\% (P2)

Nutrien broth ditimbang sebanyak 0,65 gram. Nutrient broth dimasukkan ke dalam gelas ukur yang berisi aquades sebanyak 50 ml. Glukosa sebanyak 5 gram ditambahkan ke dalam larutan NB kemudian diaduk sampai homogeny. Ditambahkan larutan $\mathrm{CH}_{3} \mathrm{COOH}$ sampai mencapai $\mathrm{pH}$ 4. Untuk memastikan $\mathrm{pH}$ mencapai 4, digunakan pHmeter. Larutan dibagi ke dalam 4 tabung reaksi masing-masing sebanyak $10 \mathrm{ml}$ menggunakan pipet mohr. Larutan yang sudah siap kemudian disterilisasi menggunakan autoclave dengan suhu $121^{\circ} \mathrm{C}$ selama 15 menit

\section{Persiapan Media Kultur NB + pH $4+$}

\section{Glukosa 30\% (P3)}

Nutrien broth ditimbang sebanyak 0,65 gram. Nutrient broth dimasukkan ke dalam gelas ukur yang berisi aquades sebanyak 50 ml. Glukosa sebanyak 15 gram ditambahkan ke dalam larutan NB kemudian diaduk sampai homogen. Ditambahkan larutan $\mathrm{CH}_{3} \mathrm{COOH}$ sampai mencapai $\mathrm{pH}$ 4. Untuk memastikan $\mathrm{pH}$ mencapai 4, digunakan pHmeter. Larutan dibagi ke dalam 4 tabung reaksi masingmasing sebanyak $10 \mathrm{ml}$ menggunakan pipet mohr. Larutan yang sudah siap kemudian disterilisasi menggunakan autoclave dengan suhu $121{ }^{\circ} \mathrm{C}$ selama 15 menit.

\section{Persiapan Media Kultur NB + pH $4+$ Glukosa 50\% (P4)}

Nutrien broth ditimbang sebanyak 0,65 gram. Nutrient broth dimasukkan ke dalam gelas ukur yang berisi aquades sebanyak 50 ml. Glukosa sebanyak 25 gram ditambahkan ke dalam larutan NB kemudian diaduk sampai homogeny. Ditambahkan larutan $\mathrm{CH}_{3} \mathrm{COOH}$ sampai mencapai $\mathrm{pH}$ 4. Untuk memastikan $\mathrm{pH}$ mencapai 4, digunakan pHmeter. Larutan dibagi ke dalam 4 tabung reaksi masingmasing sebanyak $10 \mathrm{ml}$ menggunakan pipet mohr. Larutan yang sudah siap kemudian disterilisasi menggunakan autoclave dengan suhu $121{ }^{0} \mathrm{C}$ selama 15 menit.

\section{Inokulasi Bakteri $E$. coli}

Inokulasi dilakukan secara aseptic pada ruang laminar. E. coli sebanyak $0,1 \mathrm{ml}$ ditambahkan ke dalam tiga tabung pada masing-masing perlakuan menggunakan mikropipet. Satu tabung sebagai blanko tidak ditambahkan E. coli. Pada bagian setiap penutup tabung dilapisi dengan plastic wrap untuk mencegah kontaminasi. Semua tabung yang sudah ditambahkan $E$. coli diinkubasi dalam incubator dengan suhu $37{ }^{0} \mathrm{C}$ selama 42 jam. Setiap jam ke 0; 3,$5 ; 7 ; 17 ; 29$ dilakukan pengamatan.

\section{Pengamatan Optical Density (Metode Turbidimetri)}

Sampel sebanyak 0,1 ml dimasukkan ke dalam cuvet menggunakan mikropipet kemudian diamati menggunakan spektrofotometer dengan panjang gelombang $600 \mathrm{~nm}$. Pengambilan sampel dilakukan pada jam ke $0 ; 3,5 ; 7 ; 17$ dan 29 . Data yang sudah didapat kemudian direkap ke dalam Ms. Excel. 


\section{HASIL DAN PEMBAHASAN}

Perhitungan jumlah bakteri E.coli menggunakan spektrofotometer menghasilkan nilai absorbansi yang mencerminkan tingkat kekeruhan (Optical Density). Semakin tinggi nilai OD maka semakin tinggi pula populasi bakteri. Hasil pengukuran nilai OD dapat dilihat pada tabel 1 dengan grafik pertumbuhannya pada gambar 1.

Tabel 1. Hasil pengukuran nilai OD bakteri Escherichia coli

\begin{tabular}{cccccc}
\hline Waktu (jam) & P0 & P1 & P2 & P3 & P4 \\
\hline 0 & 0,118 & 0,083 & 0,094 & 0,136 & 0,169 \\
3,5 & 0,248 & 0,043 & 0,083 & 0,447 & 0,453 \\
7 & 0,367 & 0,108 & 0,112 & 0,341 & 0,257 \\
17 & 0,356 & 0,088 & 0,187 & 0,412 & 0,718 \\
29 & 0,445 & 0,095 & 0,088 & 0,142 & 0,727 \\
\hline
\end{tabular}

Keterangan : $\mathrm{P} 0=$ Nutrien Broth + E.coli, $\mathrm{P} 1=$ Nutrien Broth + E.coli $+\mathrm{pH} 4, \mathrm{P} 2=$ Nutrien Broth + E.coli $+\mathrm{pH}$ $4+$ glukosa $10 \%, \mathrm{P} 3=$ Nutrien Broth + E.coli $+\mathrm{pH} 4+$ glukosa $30 \%, \mathrm{P} 4=$ Nutrien Broth + E.coli + $\mathrm{pH} 4+$ glukosa $50 \%$

Berdasarkan data tersebut, teramati bahwa pertumbuhan bakteri E.coli pada setiap perlakuan berbeda. Nilai OD pada kontrol yaitu nutiren broth yang ditumbuhkan E. coli terus meningkat dari jam ke-0 sampai jam ke-29. Pada saat diberi $\mathrm{CH}_{3} \mathrm{COOH}$ kondisisnya menjadi asam dengan $\mathrm{pH} 4$, nilai OD yang diperoleh lebih rendah, hal tersebut mengindikasikan bahwa populasi bakteri yang tumbuh pun lebih rendah. Rendahnya populasi bakteri pada $\mathrm{pH} \quad 4$ disebabkan oleh kondisi lingkungan yang tidak sesuai untuk pertumbuhan bakteri. Menurut Fardiaz (1989) pada kondisi pH dibawah 5,0 dan di atas 8,5 , bakteri tidak tumbuh dengan baik. Selanjutnya, pada perlakuan yang ditambahkan glukosa sebanyak $10 \%$, pertumbuhan E.coli yang terlihat lebih tinggi daripada perlakuan P1, hal tersebut menunjukkan bahwa glukosa yang diberikan berpengaruh pada pertumbuhan E.coli. Pada saat konsentrasi glukosa ditambahkan menjadi $30 \%$, pertumbuhan E.coli terus meningkat dengan nilai OD yang lebih tinggi daripada pada konsentrasi $10 \%$. Demikian pula saat konsentrasi glukosa dinaikkan sampai $50 \%$, populasi E.coli yang diperoleh lebih tinggi daripada konsentrasi $30 \%$. 


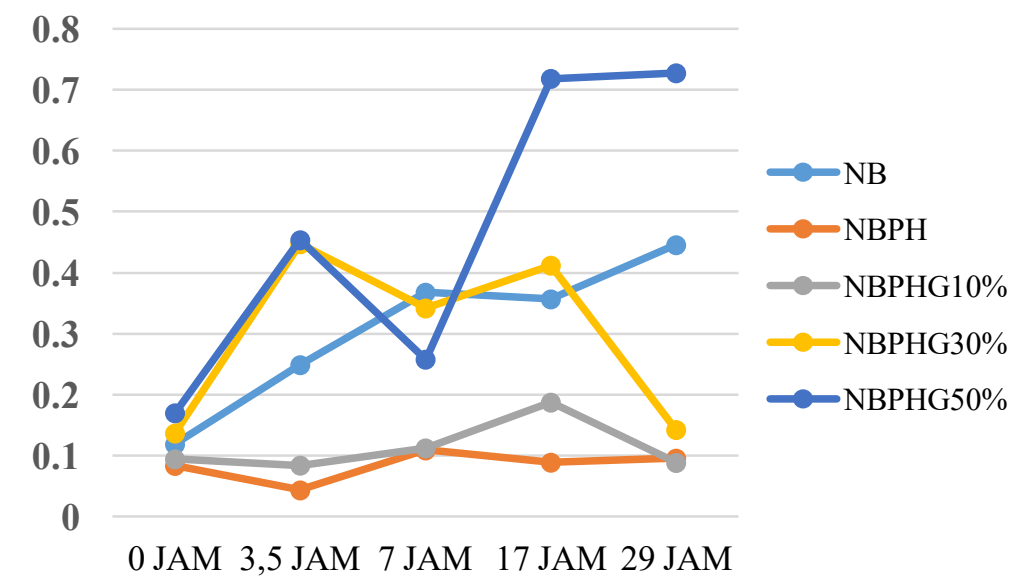

Gambar 1. Grafik Pertumbuhan E.coli

Pada saat bakteri E.coli menghilangkan agen stres (Juneja dan dikondisikan pada $\mathrm{pH} 4$, seperti yang terlihat pada $\mathrm{P} 1$, populasi bakteri menurun akibat dari perubahan kondisi lingkungannya, sesuai dengan pernyataan Pelczar dan Chan (2006) bahwa pertumbuhan mikroba sangat tergantung pada keadaan sekelilingnya. Namun, pada jam ke-7 terjadi peningkatan populasi bakteri E.coli, ternyata menurut penelitian Booth et al. (2002) pada saat E. coli dalam fase $\log$ diinduksi pada $\mathrm{pH} 5.5$ dan $\mathrm{pH} 4.3$, E. coli menstimulasi sintesis acid shock proteins (ASPs). Ketika sel mikroba terkena cekaman lingkungan, sel akan merespon dengan berbagai cara. Kemungkinan besar, gen tertentu yang berkaitan dengan respon stres sel diekspresikan, akhirnya mengarah kepad produksi protein yang dikenal sebagai shock protein. Fungsi utama protein ini adalah memperbaiki kerusakan yang disebabkan oleh faktor stres atau untuk Novak, 2003; Ohtsuka et al., 2007; Yousef dan Courtney, 2003).

Pemberian glukosa bertujuan sebagai sumber energi untuk bakteri E.coli agar bertahan pada kondisi asam dengan $\mathrm{pH}$ 4. Menurut Gorke dan Stulke 2008, glukosa merupakan sumber karbon pilihan untuk $E$. coli, seperti banyak bakteri lainnya. Keberadaan glukosa mendukung tingkat pertumbuhan lebih cepat dibandingkan dengan gula lainnya. Lebih jelasnya lagi terlihat pada grafik pertumbuhan E. coli bahwa pemberian glukosa sampai $50 \%$ masih dapat membantu bakteri E. coli untuk meningkatkan pertumbuhan populasinya sampai pada jam ke-29, sedangkan pada pemberian glukosa 10 dan $30 \%$ sudah terjadi penurunan populasi bakteri E. coli. Hal tersebut disebabkan glukosa yang berperan sebagai sumber energi telah habis digunakan. 
Keberadaan glukosa yang diberikan pada media tumbuh E. coli digunakan sebagai sumber energi bagi bakteri $E$. coli untuk mendukung kinerja pompa proton. Pompa proton merupakan sistem pada bakteri yang berguan untuk mengatur keluar-masuknya proton. Hal tersebut sesuai dengan pernyataan Purwoko (2007) bahwa faktor utama dalam homeostasis $\mathrm{pH}$ pada bakteri adalah mengatur keluarmasuknya proton. Ketika nilai $\mathrm{pH}$ intrasel menjadi sangat asam (akibat perubahan nilai $\mathrm{pH}$ eksternal menjadi asam), maka proton akan dipompa keluar. Sebuah studi terhadap pertumbuhan E. coli pada $\mathrm{pH} 5$ versus $\mathrm{pH} 7$ menunjukkan bahwa asam menaikkan pompa proton dari sistem transpor elektron dan protein membran luar (Maurer et al., 2005).

\section{KESIMPULAN}

Media dengan $\mathrm{pH}$ rendah $(\mathrm{pH}$ 4) dapat menghambat pertumbuhan bakteri E.coli, sedangkan penambahan glukosa mampu mempertahankan pertumbuhan bakteri E.coli. Penambahan glukosa sampai $50 \%$ terbukti mampu meningkatkan populasi sampai jam ke 29, sedangkan pada pemberian glukosa 10 dan $30 \%$ sudah terjadi penurunan populasi bakteri $E$. coli pada jam ke 29. Sebaiknyaa dilakukan percobaan lebih lanjut dengan kadar glukosa yang lebih tinggi, waktu pengamatan yang lebih lama dan interval pengamatan yang lebih pendek untuk mengetahui batas maksimum penggunaan glukosa serta dinamika populasi yang lebih rinci.

\section{DAFTAR PUSTAKA}

Booth, I.R., P Cash and C O'Byrne. 2002. Sensing and adapting to acid stress. Anton von Leeuwenhoek. 81:33-42.

Fardiaz, S. 1989. Fisiologi Fermentasi. Bogor. Pusat Antar Universitas. Institut Pertanian Bogor.

Gorke, B. and J. Stulke. 2008. Carbon catabolite repression in bacteria: many ways to make the most out of nutrients. Nat Rev Microbiol. 6:613-624.

Juneja, V.K. and J.S. Novak. 2003. Adaptation of foodborne pathogens to stress from exposure to physical intervention strategies. In: Yousef, A.E. and Juneja, V.K. (eds.) Microbial Stress Adaptation and Food Safety, p.159-211, CRC Press, Boca Raton.

Maurer, L.M., E. Yohannes, S.S. Bondurant, M. Radmacher and J.L. Slonczewski. 2005. pH regulates genes for flagellar motility, catabolism, and oxidative stress in Escherichia coli K-12. J Bacteriol 187:304-319. 10.1128/JB.

Ohtsuka, K., D. Kawashima and M. Asai. 2007. Dual functions of heat shock proteins: molecular chaperones 
inside the cell and danger signals outside of cells. Thermal Med. 23:11-22.

Pelczar, M.J. dan E.C.S. Chan.1988. DasarDasar Mikrobiologi jilid II. Jakarta: Penerbit Universitas Indonesia (UI Press).

Purwoko, T. 2007. Fisiologi Mikroba. Bumi Aksara. Jakarta.

Tenaillon, O., D. Skurnik, B. Picard and E. Denamur. 2010. The population genetics of commensal Escherichia coli. Nat. Rev. Microbiol. 8: 207217. doi: $10.1038 /$ nrmicro2298.
Willshaw, G.A., T. Cheasty and H.R. Smith. 2000. Escherichia coli. Di dalam: B.M. Lund, T.C. BairdParker, G.W. Gould. The Microbiological Safety and Quality of Food. Volume II. Maryland. Aspen Publisher Inc.

Yousef, A. E. and P.D. Courtney. 2003. Basics of stress adaptation and implications in new-generation foods. In: Yousef, A.E. and Juneja, V.K. (eds.) Microbial Stress Adaptation and Food Safety, p.1-30, CRC Press, Boca Raton. 